\title{
Suspicions, mere suspicions: non-conformity of the goods?
}

\author{
Ingeborg Schwenzer* and David Tebel ${ }^{\dagger}$
}

\section{Introduction}

In law, like in music or in fashion, there are trends and vogues. Some of them are global; some are more regional. After decades of discussions on market share liability and loss of a chance, it now seems fashionable to talk about suspicions as a matter of non-conformity of goods. This topic, however, seems to be most popular among German-speaking courts and scholars, with some Japanese joining the choir. The following article tries to shed some light on the various approaches used and to find a solution feasible for domestic as well as international trade.

\section{Factual analysis}

In a first step, the factual basis of the legal discussion on suspicions regarding the conformity of goods will be analysed.

\section{Examples from case law}

It all started with well-known international cases. As early as the 1960s, the German Supreme Court had to decide whether the mere suspicion that Argentinean rabbit meat was contaminated by salmonella was enough to hold the seller liable. ${ }^{1}$ The next case arose when some Austrian winemakers added glycol to their wines in order to reach the threshold for being certified as 'quality wine'. ${ }^{2}$ More recently, the Belgian pork case ${ }^{3}$ hit the headlines in regard to the UN Convention on Contracts for the International Sale of Goods (CISG). ${ }^{4}$ In this

* Ingeborg Schwenzer, Dr iur (Freiburg im Breisgau), LLM (University of California, Berkeley), full Professor of Private and Comparative Law, University of Basel.

$\dagger$ David Tebel, ref iur (Freiburg im Breisgau), Research and Teaching Assistant, University of Basel.

1 German Supreme Court (BGH), 16 April 1969, NJW 1969, 1171-2; BGH, 14 June 1972, NJW 1972, 1464.

2 BGH, 23 November 1988, NJW 1989, 218-20.

3 BGH, 2 March 2005, CISG-online 999. See also Higher Regional Court (OLG) Oldenburg, 18 June 2013, RdL 2013, 272-3 where feeding stuff was suspected to contain dioxin.

4 UN Convention on Contracts for the International Sale of Goods 19 ILM 668 (1980) [CISG].

(C) The Author (2014). Published by Oxford University Press on behalf of UNIDROIT. All rights reserved. For Permissions, please email journals.permissions@oup.com 
case, the already delivered pork had to be destroyed because it was suspected of containing dioxin.

In the meantime, German courts and scholars have discussed many other-mostly domestic - constellations under the topic of suspicion and nonconformity of the goods. These include foodstuff with manipulated packaging and labels. ${ }^{5}$ Furthermore, possible future damage to buildings caused by dry rot, ${ }^{6}$ humidity, ${ }^{7}$ or real estate with possible brownfield status ${ }^{8}$ have been discussed. Other constellations relate to motor vehicles whose prior use as rental cars, ${ }^{9}$ taxis, ${ }^{10}$ driving school cars, ${ }^{11}$ or the like have indicated increased wear and tear or possible future problems. Likewise, wrong statements regarding prior owners of cars, ${ }^{12}$ chip-tuning of cars, ${ }^{13}$ cars that have been involved in an accident, ${ }^{14}$ or inexplicable noises during the operation of a $\mathrm{car}^{15}$ may give rise to suspicions of sub-standard qualities. One may add cases to this list, in which the genetic predisposition of horses may lead to pathological symptoms. ${ }^{16}$

Finally, suspicions may not only arise in regard to the non-conformity of the goods but also with regard to third party rights, such as patents or trademarks. In a recent case decided by a German appellate court, a breach of contract was found where pharmaceutical products were suspected to be counterfeit. ${ }^{17}$

\section{Classification}

All of these cases have in common the fact that at the relevant point in time it cannot be established whether the goods actually do possess the suspected features or whether these will materialize in the future. The crucial question, therefore, is whether the suspicions themselves already suffice to render the goods

5 OLG Karlsruhe, 25 June 2008, NJW-RR 2009, 134-6.

6 BGH, 7 February 2003, NJW-RR 2003, 772-3; OLG Celle, 21 June 2012, BauR 2012, 1810-15; see Barbara Grunewald, in Walter Erman and Harm Peter Westermann (ed), Bürgerliches Gesetzbuch (13 ${ }^{\text {th }}$ edn, Schmidt 2011) s 434, para 30.

7 Regional Court (LG) Bonn, 30 October 2003, NJW 2004, 74-6.

8 BGH, 20 October 2000, NJW 2001, 64-5; OLG München, 21 April 1994, NJW 1995, 2566-7; see Grunewald in Erman (n 6) s 434, para 30.

9 OLG Köln, 29 May 1996, NZV 1997, 312-3.

10 BGH, 12 May 1976, VIII ZR 33/74; OLG Hamm, 9 February 2012, DAR 2012, 261-2; OLG Düsseldorf, 16 October 2009, 22 U 166/08.

11 OLG Hamm, 9 February 2012, DAR 2012, 261-2; OLG Düsseldorf, 16 October 2009, 22 U 166/08; OLG Köln, 29 May 1996, NZV 1997, 312-3; AG Aachen, 15 May 2012, 8 O 29/11, left open by OLG Köln, 19 February 2013, DAR 2013, 208.

12 BGH, 16 December 2009, NJW 2010, 858-9; OLG Naumburg, 6 November 2008, OLGR Naumburg 2009, 284-5; OLG Bremen, 8 October 2003, NJW 2003, 3713-4.

13 OLG Hamm, 9 February 2012, DAR 2012, 261-2; OLG Düsseldorf, 16 October 2009, 22 U 166/08.

14 BGH, 10 October 2007, NJW 2008, 53-5; BGH, 22 June 1983, NJW 1983, 2242-3; OLG Naumburg, 6 November 2008, OLGR Naumburg 2009, 284-5; Swiss Supreme Court (BGer), 4 November 1970, BGE 96 IV 145-8; Higher Regional Court (OG) Zürich, 22 November 1966, SJZ 1967, 243-4.

15 OLG Naumburg, 6 November 2008, OLGR Naumburg 2009, 284-5.

16 BGH, 7 February 2007, NJW 2007, 1351-3; OLG Celle, 31 May 2006, RdL 2006, 209-10; LG Nürnberg-Fürth, 17 December 2008, RdL 2009, 65-8.

17 OLG Düsseldorf, 14 December 2012, PharmR 2013, 177-83. 
non-conforming. However, a distinction can be drawn between the international and the domestic cases mentioned earlier. The first group may be characterized by the fact that only under the special circumstances, such as the time of delivery or the origin of the goods, are the goods suspected of having certain features that render them unfit for their ordinary purpose. For example, rabbits from Argentina are usually impeccable. Only if there have been a number of salmonella cases in Argentina will market participants react by no longer buying them. The same applies to the Belgian pork or the Austrian wine. In these cases, the market valuation of a known feature of the goods - their origin-changes under the influence of surrounding circumstances that give rise to the suspicion.

In the second group, however, market participants react to prior events that actually have affected the specific good, such as the building having been exposed to extreme humidity or pollution, the car having been used in a certain way or involved in an accident, or the genetic condition of a horse. In these cases, the market valuation of the goods is solely based on their known features and does not depend on surrounding circumstances. The feature of the goods is established as negative and the suspicion only relates to its possible consequences. ${ }^{18}$ All of these prior conditions, thus, automatically have a direct negative effect upon the goods' market value. Viewed in the right light, the latter group of cases does not raise questions of suspicion leading to non-conformity since the goods' actual features already render them non-conforming.

\section{Reference point of the suspicion}

Generally, there are two possible reference points for a suspicion. On the one hand, there may be the suspicion of a negative feature, such as in the earliermentioned cases - for example, the suspicion of rabbits being contaminated with salmonella. On the other hand, a known feature of a good can be suspected of having negative characteristics. For example, this can be the case with regard to certain additives in foodstuffs that are suspected of causing cancer or engines that are suspected of being unsuitable for use with biodiesel. ${ }^{19}$

\section{Non-conformity}

Most of the legal doctrine more or less uncritically approves the listed cases. ${ }^{20}$ Yet, this issue is a complicated one and calls for some differentiation.

18 OLG Celle, 21 June 2012, BauR 2012, 1810, 1815; OLG Naumburg, 6 November 2008, OLGR Naumburg 2009, 284-5.

19 OLG Karlsruhe, 29 May 2002, 9 U 165/01.

20 For Germany, see Walter Weidenkaff, in Otto Palandt, Bürgerliches Gesetzbuch $\left(72^{\text {th }}\right.$ edn, Beck 2013) s 434, para 58; Annemarie Matusche-Beckmann, in Julius von Staudinger (ed), J. von Staudingers Kommentar zum Bürgerlichen Gesetzbuch mit Einführungsgesetz und Nebengesetzen, 2. Buch Recht der Schuldverhältnisse, \$\$ 433-87; Leasing: (Kaufrecht und Leasingrecht) (Sellier and de Gruyter 2004) s 434, para 176; Christian Berger, in Othmar Jauernig (ed), Bürgerliches Gesetzbuch mit Allgemeinem Gleichbehandlungsgesetz (Auszug) Kommentar (14 ${ }^{\text {th }}$ edn, Beck 2011) s 434, para 14; Harm Peter Westermann, in Jürgen Säcker and Roland Rixecker (eds), Münchener Kommentar zum Bürgerlichen Gesetzbuch, Band 3 Schuldrecht, Besonderer Teil, 


\section{Suspicion as a relevant criterion for the goods' conformity}

A very far-reaching suggestion is that in the earlier-mentioned cases the mere suspicion of a negative feature cannot render the goods non-conforming. ${ }^{21}$ It is argued that only the features of the goods that can be discerned through a physical examination of the goods by the buyer can give rise to non-conformity. ${ }^{22}$ The suspicion related to the prior history of the goods such as their origin is not regarded as a case of non-conformity. Rather, this opinion suggests the seller should be liable merely under a theory of breach of information duties. ${ }^{23}$

This approach cannot convince. Today, it is widely acknowledged that nonconformity cannot only be based on the physical features but also on the legal and factual relations of the goods to their surroundings. It may even be argued that non-physical features have become more important-at least in international trade-than their physical counterparts. ${ }^{24}$ To give one example, wherever current good manufacturing practice guidelines exist, and the seller has no documentation to prove it adhered to these guidelines, the goods are non-conforming even if they are physically flawless. ${ }^{25}$ In any case, it is the goods' fitness for the particular or ordinary use that in turn is determined by the respective market expectations. For example, if goods intended for resale cannot be resold for the market price usually paid for such goods, they are non-conforming regardless whether the reason is a physical or a non-physical feature.

Decisive to determine the goods' conformity is the market's valuation of the goods' features. ${ }^{26}$ Consequently, all features that affect the market's valuation affect the goods' conformity. ${ }^{27}$ If the market attaches lesser value to a car that

$\$ \$ 433-610$, Finanzierungsleasing, HeizkostenV, BetriebskostenV, CISG ( $6^{\text {th }}$ edn, Beck 2012) s 434, para 13. For Switzerland, see Heinrich Honsell, in Heinrich Honsell, Nedim Peter Vogt, and Wolfgang Wiegand (eds), Basler Kommentar Obligationenrecht I $\left(5^{\text {th }}\right.$ edn, Helbing Lichtenhahn 2011) art 197, para 6; Arnold F. Rusch, 'Verdacht als Mangel', [2012] AJP 44-8. For the CISG, see Ulrich Magnus, in Staudinger, ibid, art 35, para 25; Ingo Saenger, in Heinz Georg Bamberger and Herbert Roth (eds), Beckscher Online Kommentar BGB (Beck 2011) art 35 CISG, para 6a; Stefan Kröll, in Stefan Kröll, Loukas Mistelis, and Pilar Perales Viscasillas (eds), UN Convention on Contracts of the International Sale of Goods (CISG) (Beck 2011) art 35, para 99.

21 Barbara Grunewald, 'Der Verdacht als Mangel' in Barabara Dauner-Lieb (ed), Festschrift für Horst Konzen zum siebzigsten Geburtstag (Mohr Siebeck 2006) 131, 134-5; Grunewald in Erman (n 6) s 434 , para 6.

22 At least with regard to agreed features, see Grunewald (n 21) 134-5; similar Hartmut Oetker and Felix Maultzsch, Vertragliche Schuldverhältnisse ( $3^{\text {rd }}$ edn, Springer 2007) para 52.

23 Grunewald (n 21) 139-40.

24 Ingeborg Schwenzer, 'Conformity of the Goods: Physical Features on the Wane?' in Ingeborg Schwenzer and Lisa Spagnolo (eds), State of Play, The 3rd Annual MAA Peter Schlechtriem (Eleven 2012) 103-12.

25 Schwenzer (n 24) 104.

26 BGH, 20 June 1968, III ZR 32/66; OLG Düsseldorf, 16 October 2009, 22 U 166/08; OLG Naumburg, 6 November 2008, OLGR Naumburg 2009, 284-5; Hans-Jürgen Müggenborg, 'Der Kauf von Altlastengrundstücken nach der Schuldrechtsmodernisierung', NJW 2005, 2810 (all referring to the perception of the trade, 'Verkehrsanschauung'); similar LG Bonn, 30 October 2003, NJW 2004, 74; Westermann in Münchener Kommentar (n 20) s 434, para 56.

27 But see Westermann in Münchener Kommentar (n 20) s 434, para 13; specifically for lifestock BGH, 7 February 2007, NJW 2007, 1351, 1352-3; OLG Celle, 31 May 2006, RdL 2006, 209. 
has been involved in an accident, such a car is non-conforming regardless of whether the consequences of the accident have been remedied entirely. ${ }^{28}$ Likewise, suspicions as to the existence of third party rights or claims may affect the market's valuation. ${ }^{29}$

With regard to the CISG, this position is confirmed by Articles 41 and 42 . These provisions protect the buyer's expectations to use the goods as envisaged under the contract not only if third party rights are established but also if they are merely claimed by the third party. This value judgment should not be confined to unestablished third party rights. Rather, the buyer is also to be protected if unestablished facts- that is, suspicions - hinder the resale or the otherwise intended use of the goods.

The criterion of resaleability for the market price also properly delimitates the respective spheres of risk of the seller and the buyer. Resaleability may not only be influenced by the features of the goods but also by a change of market demands. ${ }^{30}$ An example for the first case are smartphones of a certain brand that are under suspicion of being produced under inhumane working conditions. This suspicion will not affect the market price of smartphones in general but only the resaleability of this specific brand of smartphones. This risk is to be borne by the seller. In the second scenario, if, for example, the demand for smartphones declines because the market is saturated, the result will be a general decrease of the market price for smartphones. This general utility risk in turn must be the borne by the buyer. ${ }^{31}$

\section{Suspicion impeding the goods' use}

As laid out, suspicions mainly affect the goods' usability, particularly their resaleability. To determine whether this impediment for the goods' usability renders them non-conforming, a number of factors have been suggested.

\section{A. Unqualified relevancy of the suspicion's consequences}

Especially in German case law and scholarly writing, it is argued that not every suspicion leads to non-conformity. Rather, it is oftentimes required that the suspicion is 'based upon concrete facts ${ }^{32}$ or 'obvious'. ${ }^{33}$ Others opine that only

28 See $\mathrm{n} 14$.

29 Cf OLG Düsseldorf, 14 December 2012, PharmR 2013, 177, 179.

30 Cf with regard to this distinction BGH, 16 April 1969, NJW 1969, 1171, 1172.

31 Rolf Wank, 'Lieferung von Glykolwein als Falschlieferung - BGH, NJW 1989, 218', JuS 1990, 96, 99.

32 BGH, 16 April 1969, NJW 1969, 1171, 1171-2; BGH, 23 November 1988, NJW 1989, 210, 218; OLG Karlsruhe, 25 June 2008, NJW-RR 2009, 134; OLG Oldenburg, 18 June 2013, RdL 2013, 272; LG Lübeck, 23 September 1986, NJW-RR 1987, 243; Müggenborg (n 26), 2810. Similarly, some courts require a 'concrete suspicion': OLG Celle, 21 June 2012, BauR 2012, 1810, 1813; OLG Naumburg, 6 November 2008, OLGR Naumburg 2009, 284; OLG Celle, 21 August 2008, NJOZ 2009, 3778, 3779; OLG München, 21 April 1994, NJW 1995, 2566. Similarly, see also Rutger von der Horst, 'Mangelverdacht/Verdachtmangel: Wie verdächtig muss ein Verdacht sein?', NJOZ 2013, 385, 387, 390-1; Wank (n 31) 99.

33 OLG Karlsruhe, 25 June 2008, NJW-RR 2009, 134; OLG Celle, 21 August 2008, NJOZ 2009, 3778, 3779; OLG München, 21 April 1994, NJW 1995, 2566; Weidenkaff in Palandt (n 20) s 434, para 58. Cf also BGH, 16 June 1972, NJW 1972, 1462; BGH, 16 April 1969, NJW 1969, $1171,1171-2$. 
the suspicion of a fundamental non-conformity ${ }^{34}$ or an instance of adverse health effects $^{35}$ renders the goods non-conforming. Both arguments must be rejected.

Decisive is that the suspicion affects the market's valuation of the goods and thereby impedes their intended use by the buyer. ${ }^{36}$ Whether this reaction of the market is well founded or rational is irrelevant to determine the goods' conformity. ${ }^{37}$ A comparable situation is the seller's liability for claims by third parties. It has been argued - again almost exclusively by German scholars — that the seller is not liable in case of so-called frivolous claims. ${ }^{38}$ This argument, however, has been rightly refuted. ${ }^{39}$ As John Honnold concisely remarks, the buyer 'is not purchasing a lawsuit', regardless of how frivolous it may be. ${ }^{40}$ The same consideration applies in cases where suspicions affect the goods' use. Regardless of how unfounded these suspicions may be, the seller is liable for the goods' unrestricted usability, in particular their resaleability.

In the same vain, it is irrelevant whether the suspected feature would amount to a fundamental non-conformity or not. The fundamentality of the breach may have an impact on the remedies available for the buyer ${ }^{41}$ but cannot be invoked to answer the question of non-conformity-the breach itself. If the suspected feature does not constitute a fundamental breach, the buyer can certainly not avoid the contract, but it may still have a claim for damages as far as loss was incurred.

34 Ulrich Magnus, 'Mangelverdacht als Mangel im CISG?' in Andreas Heldrich et al (eds), Festschrift für Claus-Wilhelm Canaris zum 70. Geburtstag (Beck 2007) 257, 262; LG Bonn, 30 October 2003, NJW 2004, 74. Cf also Burghard Piltz, Internationales Kaufrecht ( $2^{\text {nd }}$ edn, Beck 2008) para 5-47; Rusch (n 20) 47.

35 Also in this direction, see OLG München, 21 April 1994, NJW 1995, 2566; LG Lübeck, 23 September 1986, NJW-RR 1987, 243.

36 BGH, 20 June 1968, III ZR 32/66; LG Bonn, 30 October 2003, NJW 2004, 74; Ulrich Magnus, in Heinrich Honsell (ed), Kommentar zum UN-Kaufrecht ( $2^{\text {nd }}$ edn, Springer 2010) art 35, para 13. With specific regard to works of art that have to be suitable to be exhibited, see Erik Jayme, 'Original und Fälschung - Beiträge des Rechts zu den Bildwissenschaften' in Gerte Reichelt (ed), Original und Fälschung im Spannungsfeld von Persönlichkeitsschutz, Urheber-, Marken- und Wettbewerbsrecht (Manz 2007) 23, 37. OLG Hamm, 13 January 2009, 19 U 85/08 is, however, too restrictive in finding that the suspicion of a work of art being counterfeit is part of the buyer's general utility risk.

37 In this regard, it is irrelevant that the market's reaction to 'atypical' prior uses of cars might not be based on an actually existing risk but merely on an 'emotional aversion' as submitted by Kurt Reinking and Christoph Eggert, Der Autokauf $\left(10^{\text {th }}\right.$ edn, Werner 2009) para 1595; similar von der Horst (n 32) 390; left open by OLG Köln, 19 February 2013, DAR 2013, 208. Generally critical towards the acceptance of unfounded suspicions as basis for non-conformity, see Hideo Nakamura, 'Conformity of Goods with Regulatory Restrictions: BGH Decisions in the Mussels and the Pork Case' (2011) 15 Vindobona Journal 53, 62.

38 Peter Schlechtriem, Internationales UN-Kaufrecht ( $4^{\text {th }}$ edn, Mohr Siebeck 2007) 165; Rolf Herber and Beate Czerwenka, Internationales Kaufrecht (Beck 1991) art 41, para 6; Alexander Lüderitz and Dirk Schüßler-Langeheine, in Hans Theodor Soergel, Wolfgang Siebert, and Jürgen F Baur (eds), Bürgerliches Gesetzbuch (13 ${ }^{\text {th }}$ edn, Kohlhammer 2000) art 41, para 7. The same view was included in Article 102(1) of the new draft Common European Sales Law, COM(2011) 635 final.

39 Ingeborg Schwenzer, in Peter Schlechtriem and Ingeborg Schwenzer (ed), Commentary on the UN Convention on the International Sale of Goods (CISG) ( $3^{\text {rd }}$ edn, Oxford University Press 2010) art 41, para 11 with further references.

40 John O Honnold and Harry M Flechtner, Uniform Law for International Sales under the 1980 United Nations Convention (4 ${ }^{\text {th }}$ edn, Kluwer 2009) art 41, para 266.

41 See for details Ulrich G Schroeter, in Schlechtriem and Schwenzer (n 39) art 25, para 6. 
Furthermore, there is no reason why only the suspicion of adverse health effects should render goods non-conforming; ${ }^{42}$ rather all suspicions that affect the market's valuation are relevant. ${ }^{43}$

\section{B. The buyer being able to dispel the suspicion}

Some courts and authors argue that there is no non-conformity if the buyer is able to easily dispel the suspicion. ${ }^{44}$ In this case, it is argued, the goods' usability is not affected significantly. This argument does not convince. The fact that the buyer is able to rectify the goods' non-conformity by dispelling the suspicion does not change their initial non-conformity. ${ }^{45}$ Again, such action might affect the possible remedies. If the suspicion can be easily dispelled, the breach is not fundamental as long as afterwards the goods' usability is not substantially restricted anymore. ${ }^{46}$

\section{Suspicions based on agreed features}

It may be doubtful whether non-conformity of the goods can be assumed if the suspicions relate to features that have been explicitly agreed upon by the parties, such as if the contract explicitly provides that the rabbits should come from Argentina. In this case, the seller prima facie is obliged to deliver rabbits from Argentina as generally agreed features prevail. It has been suggested that in such a situation the buyer thus assumes the risk that the goods are not fit for use due to the agreed feature. ${ }^{47}$ This might be true in cases where the agreed feature already restricts the usability of the goods at the time of contract conclusion. In the case laid out earlier, however, a sensible interpretation of the contract suggests otherwise. $^{48}$

At the time of contract conclusion when the parties agreed upon rabbits coming from Argentina, these rabbits were indeed resaleable. The contradiction between the agreed features and the usability is only created by subsequent circumstances not envisaged by the parties. Therefore, in such a case, the usability of the goods prevails over the agreed feature by way of exception. ${ }^{49}$ To assume the risk of a

42 OLG Karlsruhe, 25 June 2008, NJW-RR 2009, 134, 135.

43 Cf OLG Celle, 21 August 2008, NJOZ 2009, 3778, 3779.

44 BGH, 16 April 1969, NJW 1969,1171, 1171-2; OLG München, 21 April 1994, NJW 1995, 2566; LG Lübeck, 23 September 1986, NJW-RR 1987, 243; Rusch (n 20) 47.

45 Florian Faust, 'Argentinische Hasen, belgische Schweine und österreichischer Wein: Der Verdacht als Mangel' in Thomas Lobinger (ed), Festschrift für Eduard Picker zum 70. Geburtstag (Mohr Siebeck 2010) 185, 197-8.

46 Faust (n 45) 198 (also pointing to the primacy of the seller's right to cure, preventing the buyer from taking actions of cure itself).

47 Ibid 190, 193.

48 Regarding contradictions between agreed features and specific use respectively between specific and ordinary use, see also ibid 189 and 196: 'parties' will decisive'. There is no reason why in these two cases the parties' intention is decisive and in the third case of contradictions between agreed features and ordinary use it should not be.

49 The distinction that Faust (ibid 189-90) makes by attributing the usability risk to the seller if it suggests the agreed feature in knowledge of the intended use and to the buyer if it suggests the agreed feature can merely serve as a rather weak indication. 
change in the goods' usability due to an agreed feature, the buyer has to attach specific importance to the feature-for example, by expressly insisting on it.

\section{Limits of the seller's liability for suspicion}

Although the goods' usability may be restricted, there are limits to the seller's liability from a territorial as well as a temporal perspective.

\section{A. Territorial limitation}

Usually, suspicions will affect the goods' usability on a global or at least regional scale- that is, both the seller's and the buyer's country are affected. This is all the more true in today's globalized world with the instant exchange of information via the Internet. ${ }^{50}$ However, there may be cases where the use of the goods is only affected in certain countries. In particular, the feature the goods are suspected to have may be viewed as a non-conformity only in some countries, or the suspicion may lead to public action or media reports affecting the market's reaction in one country but not in others. ${ }^{51}$ For example, the suspicion of child labour might result in strong reactions by the media and affect the salability of clothing quite significantly in most of the western hemisphere, ${ }^{52}$ whereas the same suspicion might be without significant effect in some Asian, African, or even IberoAmerican countries. ${ }^{53}$ In addition, goods suspected of not being kosher or halal would probably sell without issue in mainly Christian countries, while salability in Israel or mainly Muslim countries might be restricted significantly.

Such a situation is comparable to the much discussed issue of public law requirements in the country of use. Reference can be made to the famous mussels case, where New Zealand mussels complied with the regulations in the seller's country but not with the regulations in the buyer's country. ${ }^{54}$ The issue also arose with regard to suspicions in the earlier-mentioned Belgium pork case. ${ }^{55}$ Whether the seller can be held liable for the goods' compliance with public law requirements in the country of use must be judged upon the individual circumstances of the case. ${ }^{56}$ The main criteria to be considered are whether the public law

50 Insofar the suggestion of Nakamura (n 37) 60-61 to accept non-conformities based on suspicions only in regional sales has not much weight left.

51 See Peter Schlechtriem, 'Compliance with local law; seller's obligations and liability' <http:// cisgw3.law.pace.edu/cisg/biblio/schlechtriem7.html> accessed 27 December 2013, sub II.

52 See eg the media outrage following the Gap scandal in 2007 as unveiled by The Observer and WDR Germany, The Guardian <http://www.theguardian.com/business/2007/oct/28/ethicalbusiness. india $>$ accessed 27 December 2013.

53 In these regions, almost 90 per cent of the child labour worldwide takes place, see Yacouba Diallo, Alex Etienne, and Farhad Mehran, Global Child Labour Trends 2008 to 2012, report by the International Labour Office, <http://www.ilo.org/ipecinfo/product/download.do?type=docu ment\&id=23015> 11 .

54 BGH, 8 March 1995, CISG-online 144.

55 BGH, 2 March 2005, CISG-online 999.

56 Schwenzer in Schlechtriem and Schwenzer (n 39) art 35, para 16 with further references. 
requirements in the seller's country are the same as in the country of use and what are the parties' respective standings in the market. ${ }^{57}$

\section{B. Temporal limitation}

As a starting point, according to Article 36(1) of the CISG, the seller is responsible for the goods' usability at the time of the passing of risk - that is, in most cases, at the time of delivery. It may be questionable, however, whether the seller should be held liable if the suspicion affecting the usability of the goods only arises after the conclusion of the contract but still before delivery. Two scenarios have to be distinguished. First, if the earlier-mentioned interpretation of the contract results in an agreed feature prevailing over the goods' usability, the risk of a change of the market valuation with regard to this very feature rests upon the buyer. ${ }^{58}$ However, as has been explained earlier, contract interpretation in many instances will lead to the prevalence of the goods' usability. In this scenario, the risk of any change of the market's requirements between contract formation and the passing of risk is upon the seller. ${ }^{59}$ This risk allocation is also justified since the change in the market's requirements results in a price drop of the goods that are not resalable anymore, and this price drop allows the seller to purchase cheaper goods in order to fulfil its contract, giving it an unjustified windfall profit. Therefore, if the suspicion that Argentinean rabbit meat is contaminated with salmonella and thus no longer usable arises during this period, delivering Argentinean rabbit meat would constitute a breach of contract. ${ }^{60}$

In the most problematic situation, the suspicion arises only after the passing of risk. According to Article 36(1) of the CISG, the seller is responsible if the nonconformity existed in nuce at the time of the passing of risk, although it became apparent only later. This rule has been invoked by courts and legal scholars in order to justify the seller's liability for suspicions arising only after the passing of risk. ${ }^{61}$ The argument is made in the following way. ${ }^{62}$ Argentinean rabbit meat became unsalable after delivery due to being under the suspicion of salmonella contamination. The rabbits' origin as the basis of the suspicion, however, already existed at the time of delivery. Therefore, the lack of usability already existed in nuce at the relevant time.

This argument must be rejected. At the relevant time, the rabbits' origin was not problematic and thus was no basis for any restriction of their usability. The market valuation of this feature only changed when the suspicion arose after the passing of risk. Such change, however, did not exist in nuce at the time of

57 Ibid art 35, para 16 with further references.

58 Faust (n 45) 193.

59 Ibid 195; Nakamura (n 37) 58, 62-3 (regarding change of legal requirements).

60 But see Faust (n 45) 190.

61 BGH, 14 June 1972, NJW 1972, 1464; with regard to the goods' usability, see also Faust (n 45) 195.

62 See only BGH, 14 June 1972, NJW 1972, 1464. 
delivery. ${ }^{63}$ The risk of a change of the market requirements after the passing of risk must be borne by the buyer. Otherwise, the seller could be held liable for any change of the market's requirements indefinitely or at least within the two-year period set by Article 39(2) of the CISG.

A different conclusion may only be reached under Article 36(2) of the CISG where the seller has guaranteed that the goods will remain usable for a certain period of time. The high threshold displayed in this provision would be undermined if one were to assume too readily that a certain non-conformity already existed in nuce at the time of the passing of risk under Article 36(1).

\section{Dispelling of the suspicion after delivery}

It has been argued that if the suspicion is dispelled by the seller or otherwise disproved subsequent to the passing of risk the goods' usability is not affected significantly and there is no non-conformity. ${ }^{64}$ Yet, if the goods are non-conforming at the time of the passing of risk, rendering them conforming subsequently does not change the fact that there was a breach of contract. ${ }^{65}$ Dispelling the suspicion may only be regarded as a form of the seller's cure of the nonconformity. ${ }^{66}$ This factor may be relevant in regard to the remedies available to the buyer, but it may not remove the non-conformity retroactively. In particular, if the suspicion is dispelled, the breach might not be fundamental as long as the goods' usability is fully restored. ${ }^{67}$

This outcome is confirmed by the following consideration. If the buyer incurs any loss resulting from the goods' lack of usability after the passing of risk but before the suspicion is dispelled-in particular, any lost profits or the costs of dispelling the suspicion themselves - the buyer must be able to recover this loss from the seller that delivered temporarily unusable goods. The seller is further

63 Nakamura (n 37) 59-60. Cf also OLG Hamm, 13 January 2009, 19 U 85/08, where the suspicion that a work of art was not authentic arose only after the passing of risk and was therefore found to be irrelevant for the question of conformity. But see BGH, 14 June 1972, NJW 1972, 1464, where the court found that the change of the market requirements after the passing of risk was not relevant but, rather, the mere 'possibility' that circumstances impeding the goods' resalability existed at that time. Similar OLG Karlsruhe, 25 June 2008, NJW-RR 2009, 134, 135; see also OLG Celle, 21 June 2012, BauR 2012, 1810, 1814. Yet, the mere possibility of such circumstances always exists and cannot be decisive to determine the goods' conformity. See also in this regard BGH, 7 February 2003, NJW-RR 2003, 772, where it was held that at the relevant point in time there was no suspicion but the mere possibility or 'danger' of a non-conformity that was found to be insufficient to assume a breach of contract.

64 BGH, 23 November 1988, NJW 1989, 218, 219-20; OLG Düsseldorf, 14 December 2012, PharmR 2013, 177, 179; OLG Karlsruhe, 25 June 2008, NJW-RR 2009, 134, 135; OLG Karlsruhe, 29 May 2002, 9 U 165/01; Westermann in Münchener Kommentar (n 20) s 434, para 13

65 Florian Faust, in Bamberger and Roth (n 20) s 434, para 71; Faust (n 45) 197; Grunewald in Erman (n 6) s 434, paras 6, 68.

66 Faust (n 45) 198-9.

67 Ibid 199 suggests that dispelling the suspicion 'as a rule' results in the breach being non-fundamental in the sense of $\$ 281(1)$ sentence 3 and $\$ 323(5)$ sentence 2 of the BGB without the reservation made here-that would go too far. Notably, the threshold under these provisions is significantly lower than under Article 25 of the CISG. 
liable for the remaining decreased market value the goods might retain even after the suspicion is dispelled. ${ }^{68}$

\section{Burden of proof}

As a starting point, once the buyer has physically taken over the goods, it has to prove that the goods delivered are non-conforming. ${ }^{69}$ This burden, however, is shifted if the buyer rejects the goods as non-conforming or accepts them only with reservation. ${ }^{70}$ With regard to suspicions, this rule means that the buyer has to prove that the goods' usability is restricted due to suspicions of negative features. $^{71}$

As laid out earlier, it is irrelevant whether or not the suspicion is founded; all that needs to be proven is the suspicion's impact on the goods' usability. This will be easy in cases where governmental action has been taken based on the suspicion. ${ }^{72}$ Potential actions include seizure of the goods, official warnings, or order of a recall. These actions do not necessarily have to relate to the goods sold themselves, but actions directed at comparable goods can also serve as proof that the goods' usability is restricted. In this regard, media reports can also have a comparable effect and may suffice to satisfy the buyer's burden of proof. $^{73}$ In the earlier-mentioned Argentinean rabbit case, for example, a German tabloid reported that a significant number of rabbit imports from Argentina were contaminated with salmonella. Only afterwards did the authorities act by seizing the goods and prohibiting their sale. ${ }^{74}$

In a number of cases, German courts have found that the seller must dispel the suspicion of the goods having negative features. ${ }^{75}$ If the seller does so successfully, according to this opinion, the goods are conforming. Some courts and authors interpret this approach as shifting the burden of proof regarding the goods' conformity from the buyer back to the seller. ${ }^{76}$ However, others have rightfully pointed out that the burden of proof is not the right tool to deal with the question of suspicions. ${ }^{77}$ The picture becomes clear if one looks at what the goods' defect actually is.

68 Faust (n 45) 199-200.

69 Chicago Prime Packers, Inc v Northam Food Trading Co US Ct App (7th Cir), 23 May 2005, CISG-online 1026; BGer, 7 July 2004, CISG-online 848, note 3.3; Florian Mohs, 'Case Note on BGE 130 III 258', IHR 2004, 219, 220; Schwenzer in Schlechtriem and Schwenzer (n 39) art 35, para 53 with further references.

70 BGH, 9 January 2002, CISG-online 651; BGH, 8 March 1995, CISG-online 144; Piltz (n 34) para 5-23; Schwenzer in Schlechtriem and Schwenzer (n 39) art 35, para 53 with further references.

71 According to Grunewald (n 21) 136-7, 139, merely proving a suspicion is insufficient.

72 Schlechtriem (n 51) sub II.

73 Cf BGH, 16 April 1969, NJW 1969, 1171, 1172.

74 The goods had been seized before by authorities in Hamburg but had been cleared after samples had been found to be free of salmonella. Only after the media reports did the local authorities in Hanover step in and seize the goods for good.

75 See n 63.

76 OLG Frankfurt aM, 29 January 2004, NJOZ 2004, 2851, 2853; Grunewald (n 21) 138.

77 Faust (n 45) 187-8. 
Shifting the burden of proof the way the German Supreme Court does would only be viable if the defect were the suspected negative feature. In this case, the buyer first would have to submit concrete facts that the suspicion is based on, resulting in a presumption that the suspicion is true. Then, in a second step, the seller would have to disprove this presumption by providing evidence that the goods in fact did not possess the suspected negative feature. Yet, as demonstrated earlier, the goods' defect is not the suspected feature but, rather, the lack of usability resulting from the suspicion itself. Consequently, the suspected feature neither has to be proven by the buyer nor disproven by the seller. The suspicion's impact on the goods' usability merely has to be established. The burden to do so is rightly placed on the buyer once it takes delivery of the goods without complaint. In this regard, there is no reason to distribute the burden of proof differently from other cases of non-physical non-conformities.

\section{Remedies}

In cases where the suspicion renders the goods non-conforming, the buyer can choose from various remedies. There are, however, some particularities with regard to remedies in case of suspicions that will be addressed in the following sections.

\section{Avoidance}

Avoidance under the CISG requires a fundamental breach of contract according to Article 25. Thus, the suspicion has to have a fundamental impact on the goods' usability. With regard to goods intended for resale, the usual threshold appliesthat is, it has to be impossible to resell the goods even at significant discounts. ${ }^{78}$ Usually, the suspicion will affect the goods' usability fundamentally if the negative feature the goods are suspected of having amounts to a fundamental non-conformity. ${ }^{79}$ Due to the high sensitivity towards certain negative features of the respective markets, this is particularly the case for goods that are suspected of bearing a risk of personal injury, foodstuffs that are suspected of having adverse health effects, ${ }^{80}$ or works of art suspected of being counterfeit. ${ }^{81}$ On the other hand, certain markets have a higher tolerance for suspicion-for example, in the case of livestock, not every deviation from the physiological norm that leads to the

78 BGer, 28 October 1998, CISG-online 413; CISG-Advisory Council Opinion No 5 (Ingeborg Schwenzer), The Buyer's Right to Avoid the Contract in Case of Non-Conforming Goods or Documents, 2005, para 4.3. According to Magnus (n 34) 262-3, only the risk of severe personal injury can render the goods entirely unsalable; this is too restrictive.

79 For $\$ 323(5)$ sentence 2 of the BGB OLG Düsseldorf, 16 October 2009, 22 U 166/08. The suggestion of Magnus (n 34) 264 that in cases of suspicion the breach is always fundamental roots in his requirement that the suspicion concerns a fundamental non-conformity to constitute a breach of contract in the first place, which has been rejected earlier.

80 Cf Westermann in Münchener Kommentar (n 20) s 434, para 76.

81 Angela Dechow, Die Anwendbarkeit des UN-Kaufrechts im internationalen Kunsthandel (Lit 2000) 59; cf also regarding the authenticity of works of BGH, 28 June 1972, NJW 1972, 1658; OLG Hamm, 13 January 2009, 19 U 85/08. 
suspicion of the animal developing clinical symptoms in the future renders the animal unsalable. ${ }^{82}$ It is also possible, yet unlikely, that goods will remain sellable despite the suspicion of a fundamental non-conformity because buyers view the suspicion as improbable and thus are willing to buy the goods for a reduced price. The more likely scenario is that where the suspicion of a fundamental defect renders goods non-conforming by affecting their resaleability, it does so in a fundamental way - that is, buyers are unwilling to buy the goods at all.

Furthermore, the fundamental nature of a breach can also be based on suspicions. In a recent case, the German Supreme Court had to deal with a car that had a multitude of minor defects that neither amounted in themselves nor in their sum to a fundamental non-conformity, allowing the buyer to avoid the contract. $^{83}$ The court, however, found that the great number of minor defects gave rise to the suspicion of a fundamental non-conformity, which in itself could be the basis to avoid the contract without the need for a grace period (Nachfrist). ${ }^{84}$ This case goes to show that suspicions can not only give rise to a non-conformity but also render an existing breach fundamental.

Today, according to the prevailing view, a breach is not fundamental if the seller is able to cure the defect. ${ }^{85}$ Suspicion sometimes can be cured by the seller issuing a clearance certificate that proves the suspicion wrong. ${ }^{86}$ Such certificates are, however, only a viable means of cure if they actually make the goods usable again. In most cases, a clearance certificate will not suffice to convince customers that the goods do not possess the suspected negative features. ${ }^{87}$ The burden to prove that a clearance certificate renders goods salable lies with the seller.

\section{Anticipatory breach}

It has been submitted that Articles 71 and 72 of the CISG on anticipatory breach of contract contain specific regulations on suspected non-conformities. ${ }^{88}$ This, however, is not the case. The provisions on anticipatory breach apply with regard to suspicions exactly like they do with regard to any other non-conformity. Prior to delivery, if a suspicion affects the goods' resaleability the buyer can under the prerequisites of Articles 71 and 72 suspend performance or even avoid the

82 BGH, 7 February 2007, NJW 2007, 1351-3; OLG Celle, 31 May 2006, RdL 2006, 209 (both even denying a breach of contract); but see LG Nürnberg-Fürth, 17 December 2008, RdL 2009, 65. See also Westermann in Münchener Kommentar (n 20) s 434, para 78.

83 BGH, 23 January 2013, NJW 2013, 1523-6.

84 According to Christian Erger, 'Der Rücktritt des Käufers beim “Montagsauto”, NJW 2013, 1485, 1486.

85 OLG Köln, 14 October 2002, CISG-online 709; LG München I, 27 February 2002, CISG-online 654; Schroeter in Schlechtriem and Schwenzer (n 41) art 25, para 48 with further references; Honnold and Flechtner (n 40) art 25, para 184; Piltz (n 34) para 5-279. For details, see Benjamin K Leisinger, Fundamental Breach Considering Non-Conformity of the Goods (Sellier 2007) 58-81.

86 BGH, 2 March 2005, CISG-online 999. Cf also OLG Karlsruhe, 29 May 2002, 9 U 165/01; Magnus (n 34) 263.

87 Cf Faust (n 45) 199.

88 Magnus (n 34) 265-8. 
contract. The possible, but rather unlikely, scenario that it can be established with a sufficient degree of certainty that a suspicion, which has not yet affected the salability of the goods to be delivered, will do so in the future, would also constitute an anticipatory breach of contract. Contrary to what has been suggested, however, these provisions do not contain any specific regulations on how to deal with suspicions, nor can such regulations be deduced from them.

\section{Damages}

With regard to the buyer's claim for damages, the seller's potential exemption under Article 79 of the CISG is of special relevance. As always, the seller's procurement risk under the contract serves as the starting point. ${ }^{89}$ If the suspicion arises before delivery, the seller has to procure available goods that are free from the suspicion within its procurement risk. As long as the seller is able to procure goods free from the suspicion within its procurement risk, it is irrelevant whether or not the seller has had any influence on the suspicion. ${ }^{90}$

Only where the seller is unable to procure goods free from the suspicion within its procurement risk, can it rely on exemption under Article 79 of the CISG. Such a scenario is possible in three cases. First, it is possible where there are no goods free from the suspicion available at all. Second, it is possible where goods free from the suspicion are available, but where procuring them would be too onerous for the seller and thus not part of his or her procurement risk-constituting a case of hardship. ${ }^{91}$ Third, it is possible where the seller's procurement risk under the contract is limited to a certain kind of goods that are entirely affected by the suspicion-particularly where the seller is also the manufacturer or producer of the goods and thus usually only obliged to deliver its own products. ${ }^{92}$

In all three scenarios, in order for the seller to be exempt, the requirements of Article 79 of the CISG have to be fulfilled. The crucial requirement with regard to suspicions is that the impediment has to be beyond the seller's control. The suspicion as the impediment is only beyond the seller's control if it is based on facts on which the seller has no influence. For example, if the suspicion is based on the goods' origin, it is beyond the seller's control because the seller has noreasonable-possibility to affect this origin. On the other hand, if the suspicion is based on certain manufacturing practices that the seller actually made use of in the past or a component that the goods actually contain, the suspicion is not beyond the seller's control. This is even the case if the manufacturing practice or the use of the component was state of the art at the time the seller employed it. The risk of a change of the market valuation in this regard therefore rests on the seller.

89 Schwenzer in Schlechtriem and Schwenzer (n 39) art 79, para 11, 26-7.

90 This restriction is overlooked by Carla Spivack, 'Of Shrinking Sweatsuits and Poison Vine Wax: A Comparison of Basis for Excuse under U.C.C. \$2-615 and CISG Article 79’ (2006) 27 University of Pennsylvania Journal of International Law 757, 797.

91 Schwenzer in Schlechtriem and Schwenzer (n 39) art 79, para 30, 54.

92 District Court (RB) Maastricht, 9 July 2008, CISG-online 1748, sub 3.8; Schwenzer in Schlechtriem and Schwenzer (n 39) art 79, para 27. 
In cases where the suspicion arises only after delivery - that is, after the passing of risk-there is no need for recourse to Article 79 of the CISG because, as demonstrated earlier, there already is no breach of contract.

\section{Fraud and seller's information duty}

The seller generally is under the obligation to bring to the buyer's attention all features of the goods that can potentially affect the buyer's decision to buy them, ${ }^{93}$ except those that are obvious to the buyer. ${ }^{94}$ Obviously, the buyer's decision can also be affected by existing suspicions regarding the goods. ${ }^{95}$ Some courts require a certain degree of probability that the suspicion is actually true for the seller to be under a respective information duty. ${ }^{96}$ This, however, is too restrictive. Already the not completely remote possibility that the suspicion is true can result in a negative market reaction and has to be disclosed to the buyer. If the seller intentionally conceals or keeps quiet about suspicions regarding the goods, it is acting fraudulently, and the buyer can terminate the contract based on fraudulent misrepresentation. ${ }^{97}$ The buyer can do so based on domestic law concurrently to the remedies for non-conformity under the CISG. ${ }^{98}$ This possibility is of specific importance when the parties have excluded the seller's liability for non-conformity since such exclusion generally does not encompass non-conformities the seller has fraudulently concealed. ${ }^{99}$

Under some national jurisdictions, the buyer also has remedies for negligent misrepresentation or based on culpa in contrahendo in case the seller does not fulfil its information duty negligently. ${ }^{100}$ As a general rule, these remedies cannot be relied upon concurrently to remedies for non-conformity under the CISG, because otherwise key areas of the CISG would be undermined. ${ }^{101}$

93 BGH, 16 December 2012, NJW 2010, 858; BGH, 20 October 2000, NJW 2001, 64; OLG Celle, 21 August 2008, NJOZ 2009, 3778, 3781; OLG Bremen, 8 October 2003, NJW 2003, 3713.

94 BGH, 7 February 2003, NJW-RR 2003, 772; BGH, 20 October 2000, NJW 2001, 64; OLG Celle, 21 August 2008, NJOZ 2009, 3778, 3781; OLG Bremen, 8 October 2003, NJW 2003, 3713.

95 BGH, 7 February 2003, NJW-RR 2003, 772; LG Bonn, 30 October 2003, NJW 2004, 74; Grunewald (n 21) 139.

96 LG Bonn, 30 October 2003, NJW 2004, 74; cf also BGH, 7 February 2003, NJW-RR 2003, 772.

97 BGH, 20 October 2000, NJW 2001, 64.

98 Schwenzer in Schlechtriem and Schwenzer (n 39) art 35, para 49. Under domestic German law, concurrent application is also possible. BGH, 16 December 2012, NJW 2010, 858.

99 BGH, 20 October 2000, NJW 2001, 64; OLG Celle, 21 August 2008, NJOZ 2009, 3778, 3781; LG Bonn, 30 October 2003, NJW 2004, 74.

100 Eg Germany: $\$ \$ 280(1), 241(2), 311(2)$ no 1 BGB, see Grunewald (n 21) 139; see comparatively Ingeborg Schwenzer, Pascal Hachem, and Christopher Kee, Global Sales and Contract Law (Oxford University Press 2012) paras 24.5-24.8.

101 Schwenzer in Schlechtriem and Schwenzer (n 39) art 35, para 48. Faust (n 45) 191 suggests that concurrent application should be possible since the information duty does not relate to the features of the goods but to the suspicion. This suggestion overlooks that not the feature of the goods gives rise to the non-conformity in the cases discussed but, rather, the lack of usability resulting from the suspicion. Thus, the argument that the value judgments of sales law should not be undermined by concurrent application of other remedies remains valid. 


\section{Seller's duty to dispel the suspicion}

It has been established that non-conformity is not affected by the seller dispelling the suspicion after delivery. Yet, the seller's possibility to dispel the suspicion can also be relevant when the goods are conforming-for example, if the suspicion only arises after delivery. In such a situation, the seller is obliged to assist the buyer in dispelling the suspicion and rendering the goods usable again. Possible actions of the seller include issuing clearance certificates for the goods delivered or public statements contradicting the suspicions. The basis for the seller's obligation to do so is the parties' general duty to cooperate in performing their contract. This duty can be based on Article 7(2) of the CISG and continues to exist after delivery. ${ }^{102}$ In determining the exact content of the obligation to assist in dispelling the suspicion, due consideration is to be given to the impact the actions have on the seller's interests - for example, costs incurred or business secrets revealed. Remedies for a breach of this duty include damages and-depending on the jurisdiction-specific performance.

\section{Conclusion}

It has been demonstrated that nowadays suspicions can have significant impact on the usability of goods. To appropriately distribute the risk of suspicions between the seller and the buyer a two-tier test is required. In the first step, it has to be analysed whether the suspicion results from the features of the goods sold or the specific circumstances of the sale. In the first case, the goods' non-conformity is rendered not from the suspicion but, rather, from the feature the suspicion results from. In the latter case, the suspicion's negative impact on the goods' usability forms the basis of the goods' non-conformity. Consequently, the market's reaction to the suspicion is the relevant criterion to determine whether the contract was breached. In a second step, this criterion is complemented in particular by the temporal limitation of the seller's liability under Article 36(1) of the CISG. Under this limitation, the seller is only liable if the suspicion exists at the time of the passing of risk; suspicions arising only after this point in time fall within the buyer's sphere of risk.

This approach differs from the approach taken by the German Supreme Court in essentially two ways. On the one hand, while it is ultimately decisive for the German Supreme Court whether the suspicion is true or not, the approach developed here respects the buyer's interest in receiving goods usable unimpeded by any suspicions regardless whether true or not. On the other hand, while the German Supreme Court burdens the seller with liability for suspicions arising only after the passing of risk, according to the approach developed here, the risk that the goods will become unusable after this point in time due to external circumstances lies with the buyer.

102 Schwenzer in Schlechtriem and Schwenzer (n 39) art 7, para 32; see in general Thomas Neumann, The Duty to Cooperate in International Sales: The Scope and Role of Article 80 CISG (Sellier 2012), passim. 
Furthermore, this approach remedies a fundamental flaw of the German Supreme Court's approach. It aligns the non-conformity, the temporal limitation, and the burden of proof all to one reference point-the suspicion and its consequences on the goods' usability. In contrast to this coherent approach, the German Supreme Court sees the suspicion as the non-conformity, requires only the reasons for the suspicion to be present at the passing of risk, and requires the seller to prove whether the goods actually have the suspected features.

One might ask why this discussion is mainly led by Germanic courts and legal scholars and has rarely come up in common law jurisdictions. Besides the general approach to law that may be called abstract and dogmatic in Germanic legal systems and concrete and pragmatic in common law, a possible explanation may be based upon the historical starting point of the seller's liability. ${ }^{103}$ Whereas German law focused on physical features of the goods, for common law market expectations played and still play the primary role. ${ }^{104}$ Consequently, the most relevant criterion to assess the effect of suspicions on the goods' conformity - the market's reaction - is more readily used in common law than in civil law jurisdictions, making it easier to properly handle cases of suspicions.

103 This is, eg, very prominently reflected by the methods to calculate damages. Where common law primarily relies on the market price, Germanic legal systems use a concrete calculation based on a substitute transaction.

104 This is also reflected in the warranty of merchantability, which is a core aspect of Anglo-American sales law. 